\title{
Disclosure of social information by Brazilian companies according to United Nations indicators of corporate social responsibility ${ }^{1}$
}

\section{Divulgação de informações sociais por empresas brasileiras segundo os indicadores de responsabilidade social corporativa da ONU}

\author{
Marcelle Colares Oliveira \\ Professora do Programa de Pós-Graduação em Administração da Universidade de Fortaleza e da Graduação em Ciências Contábeis da \\ Universidade Federal do Ceará • E-mail: marcellecolares@unifor.br \\ Marcia Martins Mendes De Luca \\ Professora do Programa de Pós-Graduação em Administração e Controladoria da Faculdade de Economia, Administração e Atuariais da \\ Universidade Federal do Ceará •E-mail: marcia@mmconsultoria.srv.br
}

Vera Maria Rodrigues Ponte

Professora do Programa de Pós-Graduação em Administração e Controladoria da Faculdade de Economia, Administração e Atuariais da Universidade Federal do Ceará • E-mail: vponte@fortalnet.com.br

João Ésio Pontes Junior

Mestrando em Administração de Empresas pelo Programa de Pós-Graduação em Administração da Universidade de Fortaleza

- E-mail: joaoesio@hotmail.com

\section{ABSTRACT}

Several frameworks of social information disclosure have been proposed worldwide to satisfy stakeholders' information needs. In 2008, the United Nations launched a guide with recommendations for corporate responsibility indicators in annual reports based on the Global Reporting Initiative framework and standards of the International Labour Organization, Organization for Economic Co-operation and Development and International Accounting Standards Board. The objective of the present study was to analyze the disclosure of social information by Brazilian companies of the New Market listing segment traded on the São Paulo Stock Exchange (BOVESPA) in accordance with UN indicators of corporate social responsibility. This was an exploratory and qualitative study based on a review of documents and the literature. The findings were interpreted by way of content analysis to determine the predominance of UN indicators disclosed by Brazilian enterprises. The results were compared to those of a $2008 \mathrm{UN}$ study on social information disclosure by 100 large enterprises in the top ten emerging economies in the world. The companies in our study were found to disclose most of the indicators recommended by the UN in harmony with internationally accepted standards. However, more recently introduced non-financial indicators were less frequently reported.

Keywords: Corporate Social Responsibility Indicators. Disclosure. Brazilian Companies. United Nations.

\section{RESUMO}

Diversas são as iniciativas de instituições nacionais e internacionais no sentido de se chegar a um conteúdo de informações sociais que seja evidenciado pelas empresas e atenda às necessidades dos stakeholders. Em 2008, foi lançado o Guia de Indicadores de Responsabilidade Corporativa em Relatórios Anuais, da Organização das Nações Unidas (ONU), elaborado com base no GRI, nas normas da OIT e da OCDE e alinhado às 
definições adotadas nas normas do IASB. O presente estudo tem por objetivo principal analisar a divulgação de informações sociais pelas empresas brasileiras do Novo Mercado da Bovespa, segundo os Indicadores de Responsabilidade Social Corporativa contidos no Guia da ONU. A pesquisa caracteriza-se como um estudo exploratório, de natureza qualitativa, delineado por pesquisa bibliográfica e documental. Na interpretação dos dados coletados, empregou-se a análise de conteúdo, tendo-se uma visão da preponderância da divulgação de cada um dos indicadores da ONU pelas empresas brasileiras pesquisadas. Os resultados obtidos foram comparados com os de pesquisa de 2008 realizada pela ONU, que investigou a divulgação dos seus indicadores por uma amostra de cem empresas de mercados emergentes. Observou-se que as empresas brasileiras pesquisadas divulgam indicadores sociais recomendados no Guia da ONU, alinhando sua divulgação a padrões internacionalmente aceitos. Observou-se, no entanto, que não foram divulgados, na mesma proporção, os indicadores de desempenho não financeiro, só mais recentemente recomendados.

Palavras-chave: Indicadores de Responsabilidade Social Corporativa. Divulgação. Empresas Brasileiras. Organização das Nações Unidas.

\section{INTRODUCTION}

Socioeconomic and environmental information disclosed by enterprises may be qualitative or quantitative and concern partners, internal and external stakeholders, the environment and society at large. Disclosure is usually done through social reports or sustainability reports, but there is no consensus on the ideal model and contents to be reported.

With the increasing recognition of corporate social responsibility (CSR) worldwide, social reports and sustainability reports are gaining importance. The models used for disclosure vary between countries, though differences are most often a question of emphasis. Thus, some models prioritize the environment while others highlight labor issues.

Most Brazilian companies use the reporting framework developed by the Institute of Social and Economic Analysis (IBASE). In other countries, a variety of models are available, but the most popular is the framework developed by the Global Reporting Initiative (GRI). In addition, the UN released a guide in 2008 recommending the annual disclosure of specific indicators of corporate social responsibility.

The general objective of the present study was to analyze the disclosure of social information by Brazilian companies in accordance with UN indicators of corporate social res- ponsibility. The specific objectives of the study were a) to look into the origin, evolution and initiatives of disclosure of corporate social responsibility, b) to describe CSR reporting frameworks, c) to present the UN guide on CSR indicators, d) to analyze the disclosure of UN indicators by selected Brazilian companies traded on the BOVESPA stock market in São Paulo.

In 2000, Bovespa (Brazil's main stock exchange) launched the 'New Market' listing segment for companies which voluntarily agreed to comply with higher standards of corporate governance and disclosure than normally required by law. The listing rules of the New Market segment have strengthened not only corporate governance disclosure in Brazil, but also corporate responsibility reporting as well. In 2005, BOVESPA launched the Corporate Sustainability Index (ISE), which recognizes Brazilian companies with good practices in the area of corporate responsibility and sustainable business practices. The ISE utilizes a number of measures in its compilation, including the corporate responsibility reporting of Brazilian enterprises. The effect of the ISE has been to encourage broader uptake of corporate responsibility reporting in Brazil. This is why we choose to analyze the disclosure of UN 
indicators by selected Brazilian companies traded on the BOVESPA stock market in São Paulo.

The study was exploratory and qualitative and used information collected from documents and the literature. The analysis provided an overall view of how selected Brazilian companies disclosed information according to UN indicators. The results were compared to a 2008 study by the UN on CSR disclosure, using UN indicators by the top 10 enterprises from the top 10 emerging economies in the world (UNITED NATIONS, 2008b).

By identifying how Brazilian companies are responding to stakeholders' social information needs through annual reports and other forms of communication, the present study represents an important contribution to the current national and international debate on corporate social responsibility among entrepreneurs, investors, civil society and other stakeholders in emerging economies.

\section{ORIGIN AND EVOLUTION OF CORPORATE SOCIAL RESPONSIBILITY}

There is no current consensus about the concept of corporate social responsibility. In fact, the concept is often subject to a certain reductionism, such as when it is viewed merely as the description of the totality of a company's social actions. A world leader in social responsibility, Business for Social Responsibility, defines CSR as corporate decision making based on ethical values, including legal aspects and respect for people, communities and the environment (BSR apud MACHADO FILHO, 2006, p. 24).

Sharfman (1994) observed that, in the nineteenth-century, social responsibility was strictly regulated in the U.S. and any action outside the limits of the Law was considered a decharacterization of the role and nature of the company. This concept of CSR started to change when the Weimar Constitution came into effect in Germany in 1919, presenting the concept of the social function of property, which would later serve as the basis for social democracy (LOYOLA, 2007).

In addition to the famous case of Dodge versus Ford in 1919, the Great Depression (1929) and World War II (1939-1945), with their dire socioeconomic repercussions, made authors like Berle and Means (1991) question the notion that the company is only responsible towards its shareholders, then considered passive proprietors. The expan- sion of corporations and their increasing power over society led the American courts to recognize that corporate social responsibility was not incompatible with the legal system, even if the system did not always prioritize the shareholders' immediate interests (ASHLEY, 2005).

Corporate social responsibility is a relatively recent theme: It was first mentioned in a book by Howard R. Bowen from 1953, entitled Social Responsibility of the Businessman (CARROL, 1999 apud BARBOSA; LEMME, 2007). A debate subsequently arose in the US and in Europe during the sixties, spurred by dramatic socioeconomic changes providing unprecedented transparency to social proble$\mathrm{ms}$ as individuals and groups affected by organizations started demanding the adoption of socially responsible policies (CASTRO, SIQUEIRA; KUBRUSY, 2007).

In Brazil, the introduction, though not the implementation, of CSR dates back to 1961 when the Association of Christian Entrepreneurs (ACDE) was founded. Over the years 1967-1977, ACDE successfully promoted CSR among entrepreneurs, eventually extending the debate to the four corners of the country (TORRES, 2001; CALIXTO, 2007).

The notion of social responsibility was reinforced by a number of events throughout the eighties, such as the great strikes in ABC Paulista, 
the campaign for direct presidential elections, the redemocratization process, the writing of the new Federal Constitution, the consolidation of trade unions, the emergence of NGOs and activism related to racial, gender and environmental issues. In 1981, the Brazilian Institute of Social Analysis (IBASE) was founded by the sociologist Herbert de Souza, better known as Betinho. A few years later, in 1989, entrepreneurs from São Paulo created the Association of Institutes, Foundations and Enterprises (GIFE) and, in 1993, Betinho launched a national campaign against starvation and poverty, consolidating the notion that companies can effectively contribute to social and environmental action (SHOMMER; ROCHA, 2007; TORRES, 2001).

\section{DOMESTIC AND INTERNATIONAL SOCIAL INFORMATION DISCLOSURE INITIATIVES}

In the international sphere, corporate initiatives of disclosure of social information became more consistent after Resolution \#1721 of the UN Economic and Social Council came into effect in 1972. The passing of the resolution encouraged research on the role and effects of multinational enterprises upon the development of emerging economies, culminating in the proposal of a code of corporate conduct. The same year would witness the publication of a social report by Singer the first of its type in the world (INSTITUTO ETHOS, 2007).

Soon a number of European governments were persuaded of the need to make disclosure of social information mandatory. Thus, in 1977, the French government passed a law requiring all companies with 300 or more employees to publish an annual report about their labor practices. Based on the French example, the Portuguese government made the reporting of social information mandatory in 1985 (Law \#141), as did the Belgian government in 1996. Corporate social reporting has since been an essential element of public labor policies in Belgium (FREIRE; REBOUÇAS, 2001).

The question of sustainability became more pertinent throughout the nineties. In 1992, at the second UN Conference on Environment and Development, called the 'Earth Summit', member countries signed Agenda 21 declaring their commitment to promoting sustainable development in the 21 st century.
The Conference also led to the formulation of the ISO 14000 standard with guidelines for environmental regulation. Later, in 1996, the Institute of Social and Ethical Accountability (ISEA) was established in order to promote innovative accountability, CSR practices and transparency for public and private organizations (INSTITUTO ETHOS, 2007).

Also in 1996, Denmark made it mandatory for companies traded on the stock market to publish annual environmental reports audited by external agencies. France followed suit five years later through Law \#2001-420 of the Nouvelles Régulations Économique. In 1997, an international movement for the adoption of uniform corporate reporting standards for social, economic and environmental information culminated in the Global Reporting Initiative (GRI). The same year, Social Accountability International (SAI) published certification standard SA8000, focused entirely on working conditions (INSTITUTO ETHOS, 2007).

In 2000, the UN launched the Global Compact Initiative, proposing ten principles applicable to the areas of human rights, labor, the environment and anti-corruption. Concurrently, GRI published a framework for sustainability reporting, which was revised two years later and named 'G2'. Subsequently, in 2003, ISEA launched the AA1000 Assurance Standard - a quality standard for sustainability reporting - and, more recently (2006), GRI released the latest revision of their sus- 
tainability reporting framework, called the G3 (INSTITUTO ETHOS, 2007).

During UN seminars held in 2003, stakeholders were observed to be largely dissatisfied with the quality and comparability of social reports. It was clear that bringing social reporting up to desired standards would require considerable efforts from corporations. Two years later, the Intergovernmental Working Group of Experts on International Standards of Accounting and Reporting (ISAR) published a list of the main types of stakeholders and the essential information required to satisfy their needs (UNITED NATIONS, 2008)

In 2006, ISAR presented a list of social indicators, the methodology used in their selection and some conclusions. During their 24th session, in 2007, ISAR released a guide on corporate responsibility indicators in annual reports, proposing a methodology of social reporting based on selected indicators (UNITED NATIONS, 2008).

Already in 1978, the Foundation Institute of Social and Business Development (FIDES), which since 1976 had carried out CSR studies in partnership with $\mathrm{ADCE}$, proposed a social reporting model for Brazil. Thus, in 1984, Nitrofértil, a state-owned company in Bahia, voluntarily submitted what is considered the country's first social report. In subsequent years, other large companies, such as Telebrás and Banespa, chose to increase transparency by submitting similar reports (IBASE, 2008).

In the nineties, the publication of social and environmental reports became a more widely accepted practice among Brazilian entrepreneurs. In addition, a campaign encouraging the submission of such reports was launched by IBASE in 1997, with the support of domestic and foreign companies and their representatives, the Securities and Exchange Commission (CVM) and Gazeta Mercantil - an influential Brazilian newspaper specialized in economics (BONATTO; MAUSS; MAGALHÃES, 2007; IBASE, 2008).
Another institution directlyinvolved in the disclosure of social information by Brazilian companies is the Ethos Institute for Business and Social Responsibility, founded by Oded Grajew in 1998. Two years after its foundation, the Ethos Institute published a guide for CSR reporting based on frameworks adopted in Brazil and abroad. Until 2006, the structure and contents of this guide were based on GRI and ISEA social reporting frameworks, the Ethos Institute's own CSR indicators and the model proposed by IBASE. However, in 2007, the Ethos Institute adopted the 'G3' the social reporting framework proposed by GRI in 2006 (INSTITUTO ETHOS, 2007).

In 1992, through advisory statement \#24/92, the CVM proposed the submission of a value added statement (VAS) and later, in 2000, through CVM/SNC/SEP memorandum \#01/00, companies were encouraged to submit a value added statement using a model developed by the Financial, Accounting and Actuarial Research Institute Foundation (FIPECAFI) of São Paulo University (USP). In 2005, Resolution \#1.010 of the Federal Accounting Council instituted VAS disclosure under Brazilian Accounting Technical Norm \#3.7. In 2007, Law \#11.638 (which introduced changes in the accounting sections of the Brazilian Corporate Law) obliged traded companies to disclose VAS. In 2008, the Committee on Accounting Pronouncements (CPC) published Technical Statement \#9 regarding VAS, later sanctioned by CVM Resolution \#557 on November 12 the same year (The "Committee on Accounting Pronouncements"(CPC) set up in 2005 of a non-governmental multi-disciplinary accounting standard setting body. Seated in its board are representatives of listed companies, auditors, securities analysts, accountants, the São Paulo Stock Exchange and academics.)

\subsection{IBASE indicators}

IBASE's 1997 social reporting framework - referred to as the 'BS' has been revised three 
times but is still contained on a single page, preserving two of its main characteristics: comparability and simplicity. The BS presently features 51 indicators, of which only eight are qualitative. These indicators cover two years of company exercise and are disposed in seven categories: Basic financial data, internal social indicators, external social indicators, environmental indicators, workforce indicators, information on the exercise of corporate citizenship, and other relevant information (IBASE, 2008).

The basic financial indicators are net revenues, operational outcome and gross salaries. The internal social indicators include both mandatory and voluntary investments to the benefit of workers, such as food, labor taxes, social security, health care, education, culture, professional training/development, child day care services and participation in profits. External social indicators cover investments benefiting society, such as schooling, culture, health and sanitation, sports, food security and child day care services (IBASE, 2008).

The environmental indicators reflect investments in technological innovation or environmental awareness programs implemented by the company to compensate for potentially negative environmental impacts or to help preserve the environment in general. They also make it possible to report investments in environmental actions or programs not directly related to the company's area of activity and to observe the company's goals related to eco-efficiency (IBASE, 2008).

The workforce indicators show how companies deal with issues like employment creation, outsourcing and the presence of female, Afro-Brazilian or handicapped professionals in managing positions. Information concerning the exercise of corporate citizenship encompasses company actions directed toward specific target groups, especially internal stakeholders (qualitative indicators). Other relevant information may include statements of non-use of child or slave labor or show how CSR practices are implemented by businesses (INSTITUTO ETHOS, 2007).

\subsection{GRI indicators}

The first version of the GRI sustainability reporting framework was launched in 2000. Two subsequent versions were launched in 2002 and 2006, respectively, revised by consensual validation with the participation of companies and civil society in a number of countries. The latest version of the framework - the 'G3' covers a wide scope of disclosure through an array of economic, environmental and social indicators (GLOBAL REPORTING INITIATIVE, 2006; INSTITUTO ETHOS, 2007).

The economic sustainability indicators of the G3 reflect the company's impact on stakeholders' economic situation and on the local, national and global economy. They evidence capital flow between stakeholders and the main economic impact produced on society as a whole. The economic section of the G3 is segmented into 'economic performance', market presence' and 'indirect economic impacts'. It is an important component in the framework since financial data, though indispensable, cannot contain all the information required to determine a company's contribution to the sustainability of the economic system in a wider sense (GLOBAL REPORTING INITIATIVE, 2006).

The environmental sustainability indicators reflect the company's impact on the environment through parameters like materials, energy, water, biodiversity, emissions/ effluents/residues, products and services, compliance and transportation. Thus, social information is provided about the company's policies on inputs (materials, energy, water), nature and biodiversity, production (control of greenhouse gas emissions) and waste management (quality and destination of wastewater) (GLOBAL REPORTING INITIATIVE, 2006). 
The social sustainability indicators of the G3 are segmented into four subcategories: labor practice/decent work, human rights, society and product responsibility, by which it is possible to measure a company's impact on the social systems with which it interacts.

The subcategory 'labor practice/decent work' is based on internationally recognized principles, such as the UN human rights declaration and the standards of the International Labor Organization (ILO), and involve aspects like labor, workers and corporate governance relations, health and occupational safety, training/education and diversity/equality of opportunity. The subcategory 'human rights' deals with aspects related to external groups (suppliers and partners) and internal groups (training in human rights for security personnel, nondiscrimination, freedom of association, child labor, slave labor and indigenous people's rights) (GLOBAL REPORTING INITIATIVE, 2006).

The category 'society' focuses on the disclosure of risk management practices associated with the company's interaction with other social institutions, with special emphasis on the problems of corruption, public policy lobbying and monopolization. Finally, the subcategory 'product responsibility' shows how consumers are directly affected by the company's products and services with respect to health and safety, labeling, compliance, marketing and privacy (GLOBAL REPORTING INITIATIVE, 2006).

\subsection{UN indicators}

The UN guide on corporate responsibility indicators in annual reports is based on the GRI framework and on ILO and OECD standards, and is compatible with the standards of the International Accounting Standards Board (IASB).

The first section of the UN document deals with stakeholders and their information needs. The second section lists the criteria for selecting core indicators according to quality characteristics (comparability, relevance and materiality, understandability, reliability and verifiability), guiding principles (universality to maximize comparability, capability of consistent measurement, performance orientation rather than process orientation, and national reporting and positive corporate contributions to development) and constraints (costs and benefits, confidentiality and timeliness).

The third section of the UN document provides an overview of 16 CSR indicators distributed in six groups: 'trade, investment and linkages', 'employment creation and labor practices', 'technology and human resource development', 'health and safety', 'government and community contributions', and 'corruption' (UNITED NATIONS, 2008).

The first group contains four indicators: total revenues, value of imports vs. exports, total new investments and local purchasing. The total revenues of a company make it possible to estimate its economic relevance to the economy in which it operates. As for the second indicator, since the value of a company's exports in relation to its imports indicates its contribution to the balance of payments of the country, it is especially relevant in developing countries with limited "hard currency" reserves. New investments, both tangible and intangible, can produce positive economic and social impacts by developing productive capacity and reducing poverty. Finally, local purchasing generally indicates the extent of a company's linkages with the local economy.

The second group also features four indicators: total workforce, employment wages and benefits, employee turnover rate, and percentage of employees covered by collective agreements. Total workforce, with breakdown by employment type, employment contract and gender - shows the positive effects of employment creation and efforts made to fight discrimination and promote human rights. Through the multiplier effect, 
employee wages and benefits may support the economic activity and development of the community. Workforce turnover rates reflect job security and employment practices. Finally, the percentage of employees covered by collective agreements shows the extent to which collective bargaining is recognized and used as a means of achieving greater social development (UNITED NATIONS, 2008).

The third group has three indicators: expenditure on research and development, average hours of training per employee, and expenditure on training. The first indicator is important as it is often associated with competitive advantage. The two other indicators - average hours of training per year per employee, broken down by employee category, and expenditure on employee training per year per employee, broken down by employee category - are intrinsically tied up with the question of technological change (UNITED NATIONS, 2008).

Group four has only two indicators: cost of employee health and safety, and work days lost due to occupational accidents, injuries and illness. Employee health and safety represent one of the greatest responsibilities of the company, especially in countries with weak regulatory infrastructure. Low investments in health could be symptomatic of poor management practices. The second indicator suggests the importance a company attributes to employee health and is therefore inversely proportional to the first indicator (UNITED NATIONS, 2008).

The two indicators of the fifth group are payments to government and voluntary contributions to civil society. In some cases, payments to government constitute a company's most significant contribution to economic development. Likewise, many companies support communities through voluntary donation of money, goods and services. Such contributions may result in improvements to local infrastructure, including sanitation, schools and hospitals (UNITED NATIONS, 2008).

Finally, the sixth group in the UN framework has but a single indicator - number of convictions for violations of laws and regulations. The amount of money paid in fines can tell stakeholders something about a company's legal liabilities and areas in need of greater control (UNITED NATIONS, 2008).

\section{METHODOLOGY}

This was a qualitative, exploratory study, based on a review of documents and literature. Exploratory, because no other study has to our knowledge been published on social information disclosure in Brazil using UN indicators. Qualitative because, instead of using large samples and statistics, the theme is explored in depth through the analysis of specific cases.

The documents reviewed were annual social and sustainability reports and investor-related information posted on company web sites (such as the standard annual financial information supplied on BOVESPA's homepage). All documents were for the year 2007.
Figure $1 \oslash$ shows the framework used in our analysis: 6 groups (or 'categories') segmented into 16 CSR indicators (or 'subcategories') recommended by the UN.

Based on the UN guide on CSR indicators, a data collection instrument was developed for use in Brazil. The instrument was filled out with data from each company researched and used to produce an overview of their CSR disclosure.

The data were interpreted by way of content analysis, identifying in the documents of each company contents converging with the standards recommended by the UN for each indicator. Thus, information related to each recommended indicator was collected from the documents and quantified. 


\begin{tabular}{|c|c|}
\hline Category & Subcategory \\
\hline \multirow{4}{*}{$\begin{array}{l}\text { Trade, investment and } \\
\text { linkages }\end{array}$} & 1. Total revenues \\
\hline & 2. Value of imports vs. exports \\
\hline & 3. Total new investments \\
\hline & 4. Local purchasing \\
\hline \multirow{4}{*}{$\begin{array}{l}\text { Employment creation } \\
\text { and Labour practices }\end{array}$} & 5. Total workforce with breakdown by employment type, employment contract and gender \\
\hline & 6. Employee wages and benefits with breakdown by employment type and gender \\
\hline & 7. Total number and rate of employee turnover broken down by gender \\
\hline & 8. Percentage of employees covered by collective agreements \\
\hline \multirow{3}{*}{$\begin{array}{l}\text { Technology and Human } \\
\text { Resource Development }\end{array}$} & 9. Expenditure on research and development \\
\hline & 10. Average hours of training per year per employee broken down by employee category \\
\hline & $\begin{array}{l}\text { 11. Expenditure on employee training per year per employee broken down by employee } \\
\text { category }\end{array}$ \\
\hline \multirow{2}{*}{ Health and safety } & 12. Cost of employee health and safety \\
\hline & 13. Work days lost due to occupational accidents, injuries and illness \\
\hline \multirow{2}{*}{$\begin{array}{l}\text { Government and Com- } \\
\text { munity Contributions }\end{array}$} & 14. Payments to government \\
\hline & 15. Voluntary contributions to civil society \\
\hline Corruption & $\begin{array}{l}\text { 16. Number of convictions for violations of corruption-related laws or regulations and } \\
\text { amount of fines paid/payable }\end{array}$ \\
\hline
\end{tabular}

\section{ANALYSIS OF DISCLOSURE OF SOCIAL INFORMATION BY BRAZILIAN COMPANIES ACCORDING TO UN INDICATORS OF CORPORATE SOCIAL RESPONSIBILITY}

\subsection{Introductory considerations}

The actual reporting practices of 39 leading enterprises in Brazil were tested against the 16 indicators identified in the UNCTAD CR Guidance. The sample used in this study is comprised of Brazilian companies in the New Market (Novo Mercado) listing segment of the BOVESPA stock market until April 2008 (in 2008, the name of the stock market was changed to BM\&F BOVESPA). The Brazilian companies of the New Market are subject to higher corporate governance and reporting standards. The 39 companies included in this study represent various sec- tors of activity. Sector classification followed the model proposed by the CVM, comprising 25 sectors, five of which were not represented in the New Market listing segment of the BM\&F BOVESPA at the time the study was initiated. Of the remaining 20 sectors, nine are represented in this study. These 9 sectors were chosen randomly from the 20 that have companies listed in the New Market and all companies from these 9 sectors were researched. These 39 companies comprise all the companies in the randomly selected 9 sectors that belong to the New Market (Figure 2) $\bullet$. 


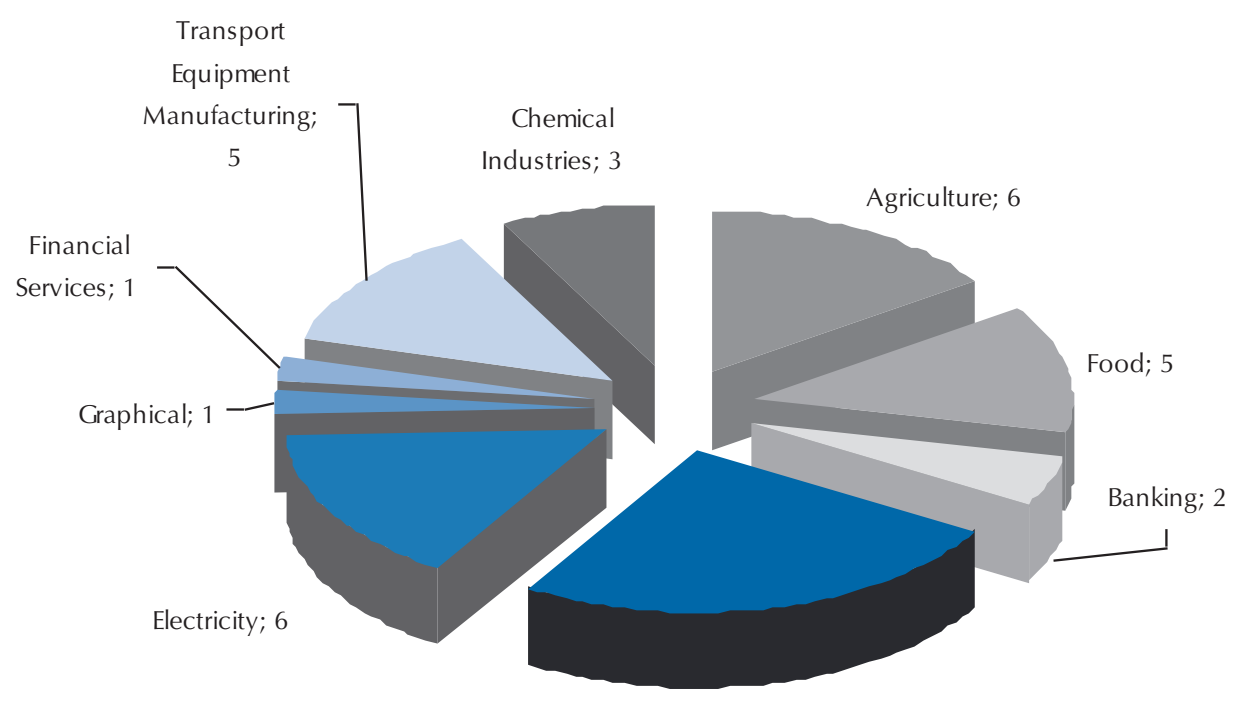

Commerce; 10

Figure 2 Distribution by sector of the 39 companies included in the study

Among the 39 companies included in the study, twenty used no specific social reporting framework, while nineteen used one or more frameworks. Of these, three companies used three frameworks (BS-IBASE, VAS and G3), eight companies used two frameworks (IBASE+VAS=6; G3+VAS=2), and eight used a single framework (IBASE $=2$; VAS=6). In other words, VAS was used by seventeen companies, BS-IBASE was used by eleven, and G3 was used by five. The twenty companies which did not use any of the frameworks described in the study disclosed social information through administrative reports, notes to the annual statements, institutional websites and specific BOVESPA documents. Such documents were also used for complementary disclosure by the nineteen companies using standard reporting frameworks.

\subsection{Disclosure practices: an overview}

The reporting of the CR indicators was classified as either "full" or "partial". This classification reflects the different ways in which enterprises report on the same matters, with some enterprises reporting more completely on each indicator, and others that provide some but not all of the information recommended in the UNCTAD CR Guidance. For example, when considering the indicator "employee wages and benefits", an enterprise that reports on the total amount of employee wages, but not on the value of benefits, would be considered to have had partial disclosure (for details of full disclosure for each of the 16 indicators, please see the UNCTAD publication, Guidance on Corporate Responsibility Indicators in Annual Reports). Figure $3 \oslash$ shows how the 39 companies disclosed social information related to the $16 \mathrm{UN}$ indicators of corporate social responsibility.

The main findings show that the five most frequently disclosed indicators by the companies included in this study were, in decreasing order, 1) total revenues, 2) total new investments, 3) payments to government, 4) total workforce with breakdown by employment type, employment contract and gender, and 5) voluntary contributions to civil society. With the exception of voluntary contributions, the same indicators were found to be the most frequently reported in UNCTAD'S 2008 CR Review, which examined the disclosure practices of 100 enterprises from 10 emerging markets. 


\begin{tabular}{|c|c|}
\hline Corporate responsibility indicators by category & $\begin{array}{l}\text { No. of enterprises } \\
\quad(\max .=39)\end{array}$ \\
\hline \multicolumn{2}{|l|}{ Trade, investment and linkages } \\
\hline Total revenues & 39 \\
\hline Value of imports vs. exports & 16 \\
\hline Total new investments & 39 \\
\hline Local purchasing & 2 \\
\hline \multicolumn{2}{|l|}{ Employment creation and labor practices } \\
\hline Total workforce with breakdown by employment type, employment contract and gender & 32 \\
\hline Employee wages and benefits with breakdown by employment type and gender & 25 \\
\hline Total number and rate of employee turnover broken down by gender & 14 \\
\hline Percentage of employees covered by collective agreements & 5 \\
\hline \multicolumn{2}{|l|}{ Technology and human resource development } \\
\hline Expenditure on research and development & 19 \\
\hline Average hours of training per year per employee broken down by employee category & 13 \\
\hline Expenditure on employee training per year per employee broken down by employee category & 17 \\
\hline \multicolumn{2}{|l|}{ Health and safety } \\
\hline Cost of employee health and safety & 14 \\
\hline Work days lost due to occupational accidents, injuries and illness & 6 \\
\hline \multicolumn{2}{|l|}{ Government and community contributions } \\
\hline Payments to government & 39 \\
\hline Voluntary contributions to civil society & 30 \\
\hline \multicolumn{2}{|l|}{ Corruption } \\
\hline $\begin{array}{l}\text { Number of convictions for violations of corruption related laws or regulations and amount of fines } \\
\text { paid/payable }\end{array}$ & 2 \\
\hline
\end{tabular}

(Number of enterprises reporting each indicator, both full and partial disclosure)

Figure 3 Reporting of ISAR corporate responsibility indicators among 39 Brazilian enterprises

The five least frequently disclosed indicators by the companies included in this study were, in decreasing order: 1) average hours of training per year per employee broken down by employee category; 2) work days lost due to occupational accidents, injuries and illness; 3) percentage of employees covered by collective agreements; 4) local purchasing; and 5) number of convictions for violations of corruption-related laws or regulations and amount of fines paid/payable. The first two of these are not among the five least frequently disclosed indicators in UNCTAD'S 2008 CR Review.

About half of the companies in the study (20 of the 39 ) reported information on 8 or more of the 16 indicators recommended in the UNCTAD CR Guidance. A significant propor- 
tion of the reporting contained partial disclosures, suggesting that the UNCTAD CR Guidance provides for further details of reporting than many companies are currently using.

The companies included in the study disclosed 3-14 out of 16 possible indicators. Thus, not even companies with high levels of disclosure followed UN recommendations completely, disclosing all 16 indicators with the recommended level of detail.

To analyze the predominance, degree of disclosure and absence of certain indicators, the findings of the study were organized according to category.

\subsection{Trade, investment and linkages}

Figure $4 \boldsymbol{\nabla}$ shows disclosure related to trade, investment and linkages: total revenues, value of imports vs. exports, total new investments and local purchasing.

In this category total revenues were fully disclosed by all companies. This is explained by the fact that businesses are required by Brazilian accounting law to inform their revenues in their annual financial reports. The least disclosed indicator was local purchasing, probably because it is not a requirement in financial reports or complementary documents submitted to BOVESPA or the CVM. Interestingly, the only two enterprises disclosing local purchasing were electricity suppliers; one is controlled by a French-Belgian group, the other is Portuguese and one of the largest European companies in the sector. These companies may be subject to stricter regulations and greater external pressures for disclosure than companies of Brazilian capital.

In addition to total revenues, seventeen companies disclosed value added and its distribution to employees, investors, shareholders, the government etc.

In spite of the importance of the value of imports vs. exports as an indicator of a company's contribution to the balance of payments of the country, only sixteen companies disclosed this information (value of imports $=3$; value of exports $=13$ ). No company disclosed both. The remaining 23 companies provided no information related to this indicator.

New investments can have a positive economic and social impact and lead to the development of productive capacity and the reduction of poverty while improving the image of the company. This fact may explain that 38 companies in our study disclosed information on their investments with the level of detail recommended by the UN. Only one company supplied no details.

As for the two most universally disclosed indicators, total revenues are generally informed in compliance with the law, while new investments are disclosed in view of their po-

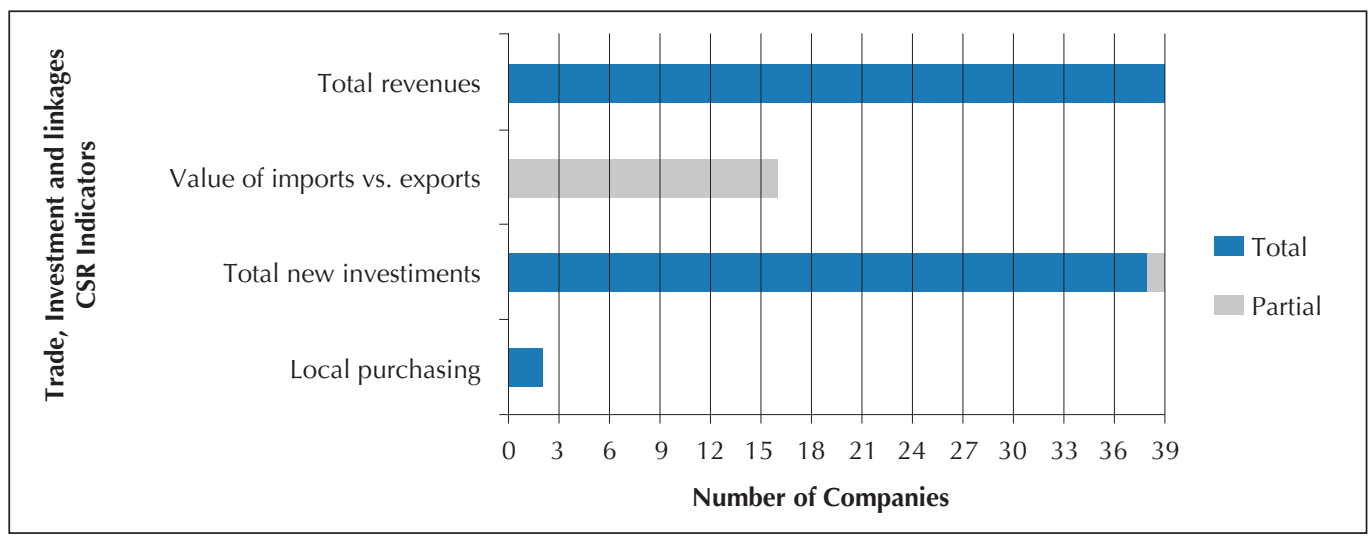


sitive impact on the company image. The two least frequently disclosed indicators (value of imports vs. exports and local purchasing) are rarely disclosed because they are not required by law. This may explain why VAS, which like total revenues will soon be an item of mandatory disclosure, is informed by almost half the companies included in the study.

Our findings for disclosure of trade, investment and linkages match findings from a study (United Nations, 2008b) on UN indicators of CSR by 100 large enterprises in the top ten emerging economies of the world. In that studyn $100 \%$ of the companies informed total revenues, 92\% disclosed new investments, 25\% declared value of imports vs. exports, while only $10 \%$ reported local purchasing. In addition, many companies provided incomplete information for the last three of these indicators. Although the two studies are comparable, it should be observed that a smaller proportion of Brazilian enterprises reported value of imports vs. exports and local purchasing.

\subsection{Employment creation and labor practices}

Figure 50 shows disclosure related to employment creation and labor practices (total workforce, employment wages and benefits, employee turnover rate, and percentage of employees covered by collective agreements).

One of the most significant positive economic and social contributions of an enterprise is the creation of jobs. Nevertheless, seven of the 39 companies analyzed disclosed none of the respective indicators in the UN guide. As shown in Figure 5, 32 enterprises reported numbers of employees. Among these, 4 broke down information by employment type, employment contract and gender, while the remaining 28 companies provided information below the level of detail recommended by the UN.

Twenty-four companies disclosed information on employee wages and benefits, but only one provided a breakdown by employment type and gender.

The employee turnover rate reflects job security and employment practices in a company. However, only 14 companies disclosed this indicator and details were lacking. This matches findings from the UN study (United Nations, 2008b) in which only 15 of 100 enterprises reported turnover rates, 9 of which with details on gender and reason for turnover.

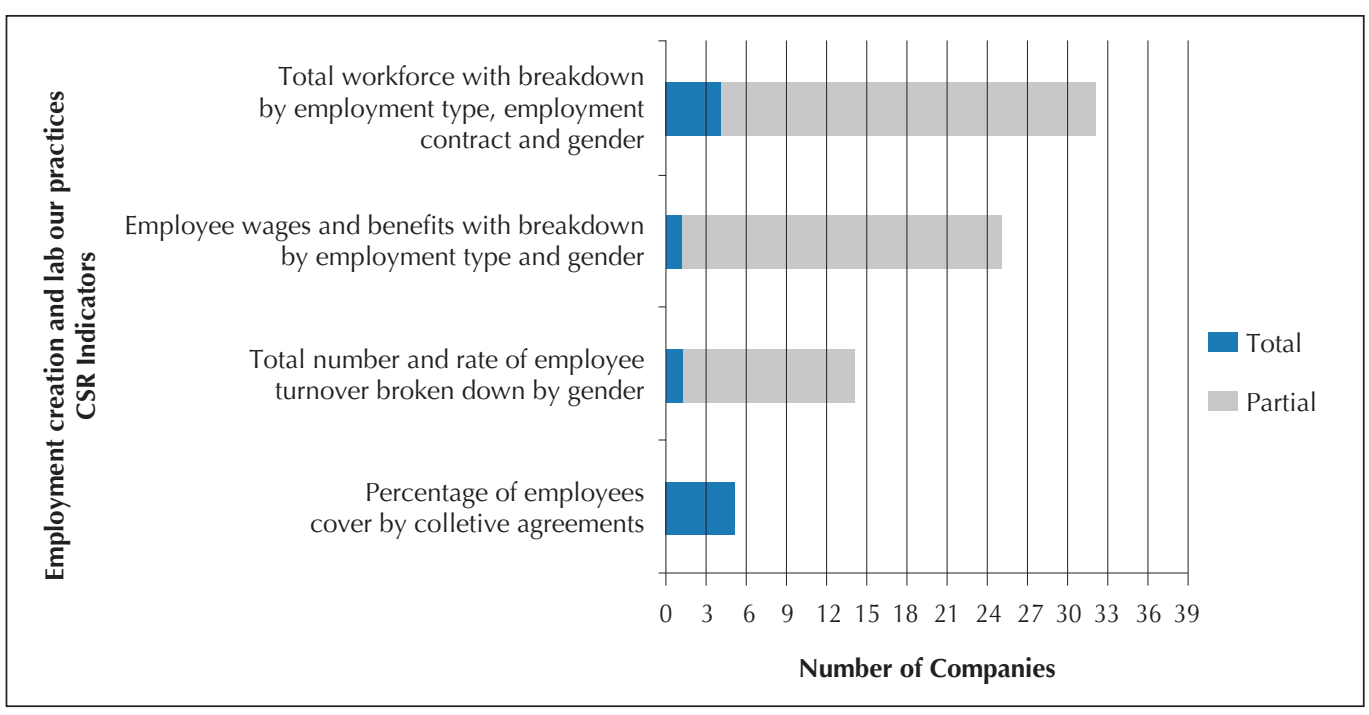


The percentage of employees covered by collective agreements indicates the workers' ability to bargain individually or collectively with their employer and the ensuing positive social impact of the business. As in the UN study, only a small number of companies (5) reported this indicator (United Nations, 2008b).

The indicators 'total workforce' and 'employee salaries and benefits' were some of the most frequently reported by the companies in our study probably because its relation to mandatory financial disclosure. On the other hand, the indicators most recently included in social information disclosure frameworks are still infrequently reported by enterprises.

\subsection{Technology and human resource development}

Figure 60 shows the quantitative distribution of companies disclosing the three indicators of technology and human resource development. The indicator 'expenditure on research and development' was informed by 19 of 39 companies, 13 of which with all the details recommended by the UN. This matches the results of the UN study (United Nations, 2008b) in which approximately half the enterprises (49) disclosed such expenditures.

The UN guide on CSR reporting contains two indicators of human resource development: average hours of training per year per employee and expenditure on employee training per year per employee. Thirteen enterprises in our study reported the former and seventeen disclosed the latter. Of this total, only three and one, respectively, included all the details recommended by the UN.

\subsection{Health and safety}

In this group, 14 companies provided information on cost of employee health and safety and on work days lost due to occupational accidents, injuries and illness. Ten of these submitted fully detailed reports.

\subsection{Government and community contributions}

Payments to government were informed by all 39 companies, while voluntary contri-

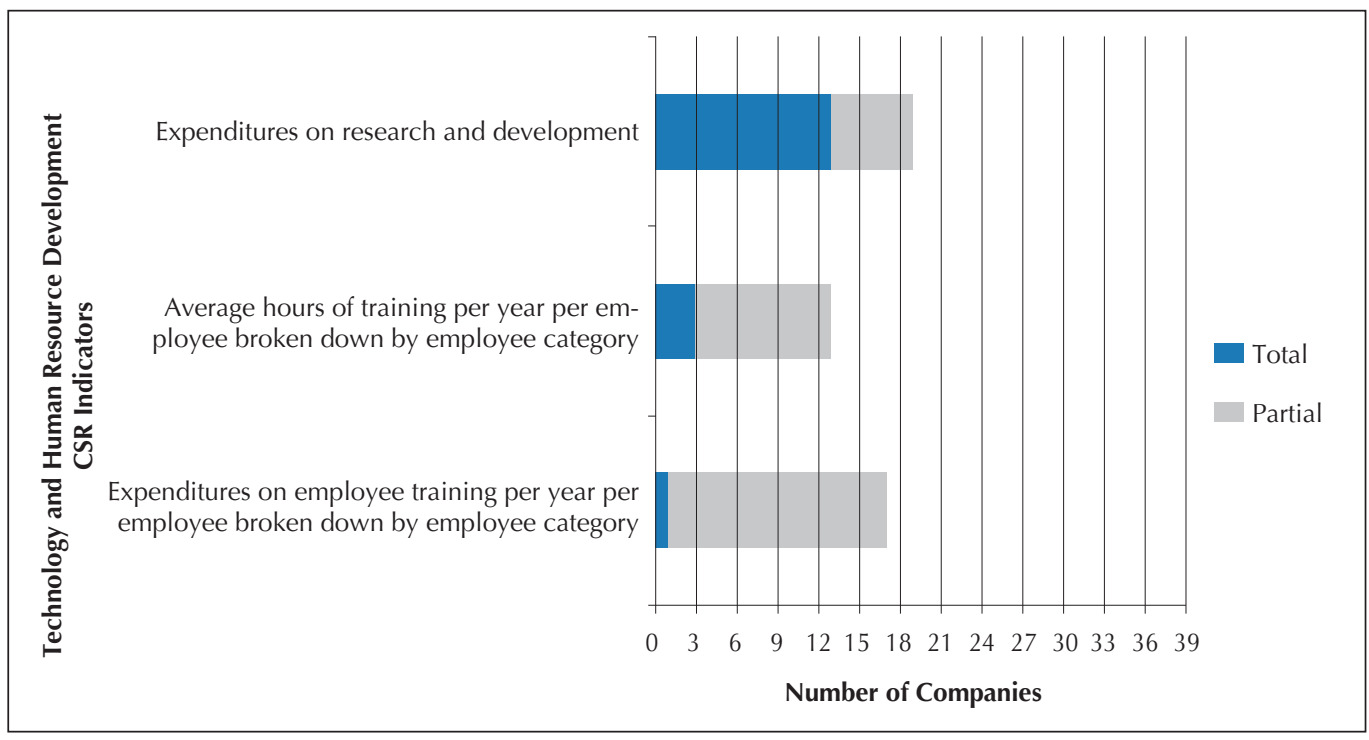

Figure 6 Technology and human resource development. Disclosed indicators and degree of disclosure 
butions to civil society were reported by 30 . Compared to the UN study (United Nations, 2008 b), a greater proportion of the companies in our study disclosed this information $(39 / 39$ vs. $88 / 100$ and $30 / 39$ vs. $60 / 100$, respectively). In Brazil, the first of these indicators is mandatory in conventional financial reports.

\section{Closing remarks}

The five most frequently disclosed indicators by the companies included in this study were, in decreasing order, 1) total revenues, 2) total new investments, 3) payments to government, 4) total workforce with breakdown by employment type, employment contract and gender, and 5) voluntary contributions to civil society. With the exception of voluntary contributions, the same indicators were found to be the most frequently reported in the 2008 UN study on CSR disclosure practices of the top 10 enterprises from the top 10 emerging economies. The results show that the most frequently disclosed social indicators are those required in conventional financial reports or in the most commonly used social reports, such as the VAS, GRI G3 and the Brazilian BS-IBASE.

The five least frequently disclosed indicators by the companies included in this study were, in decreasing order, 1) average hours of training per year per employee broken down by employee category, 2) work days lost due to occupational accidents, injuries and illness, 3) percentage of employees covered by collective agreements, 4) local purchasing, and 5) number of convictions for violations of corruptionrelated laws or regulations and amount of fines paid/payable. The first two of these are not among the five least frequently disclosed indicators in the 2008 UN study. The results indicate that the least frequently reported indicators are related to non-financial performance and are relatively recent additions to CSR disclosure frameworks, suggesting the need

\subsection{Corruption}

The least reported indicator was that of 'corruption'. A single company informed amounts paid plus details while another provided merely non-quantitative information. A similar trend was observed in the UN study (United Nations, 2008b), with only 8 of 100 companies reporting information of this type.

to reinforce the culture of social information disclosure and promote further studies into stakeholders' information needs.

While corporate responsibility reporting remains a relatively novel concept in many countries, the findings of this study suggest that it has become a somewhat common practice among leading large enterprises in Brazil. This situation can be credited, at least in part, to the more thorough reporting requirements of the New Market listing segment of the BOVESPA stock exchange. The depth of CR reporting, however, can vary. As this report finds, some CR indicators are widely reported, while others are the subject of much less frequent disclosure. It has also been noted that many indicators of corporate responsibility are not the subject of the kind of full and detailed disclosure recommended by ISAR. Thus room for the harmonization of reporting practices exists.

Policymakers may wish to consider additional steps to advance enterprises' voluntary reporting of corporate responsibility information. Additional steps might seek to standardize such information around a single set of high quality indicators, such as the core set of quantitative indicators recommended by ISAR, or the broader set of both quantitative and descriptive indicators found in the guidelines of the Global Reporting Initiative. Other policy options already practiced in some countries include:

(a) Recognition by a securities exchange regulator or stock exchange of a single re- 
commended standard for voluntary reporting of CR information.

(b) Adoption by a securities exchange regulator or stock exchange of a 'report or explain' approach whereby listed enterprises could voluntarily report CR information to the recommended standard, or explain why they do not.

\section{References}

ASHLEY, P. A. (Coord.). Ética e responsabilidade social nos negócios. 2. ed. São Paulo: Saraiva, 2005.

BARBOSA, L. N.; LEMME, C. F. A relação entre responsabilidade social corporativa e criação de valor para os investidores: o caso da Petróleo Brasileiro S. A. (Petrobras). In: ENCONTRO DA ANPAD, 31., 2007, Rio de Janeiro. Anais... Rio de Janeiro: ANPAD, 2007. BONATTO, A.; MAUSS, V.; MAGALHÃES, J. M. Ética e responsabilidade social: um estudo comparativo do balanço social da empresa Eletrocar. In: ENCONTRO DA ANPAD, 31., 2007, Rio de Janeiro. Anais... Rio de Janeiro: ANPAD, 2007.

CALIXTO, L. Responsabilidade social corporativa no Brasil: um estudo longitudinal. In: ENCONTRO DA ANPAD, 31., 2007, Rio de Janeiro. Anais... Rio de Janeiro: ANPAD, 2007.

CASTRO, F. A. R.; SIQUEIRA, J. R. M.; KUBRUSY, L. $\mathrm{S}$. A influência da responsabilidade social coorporativa no comportamento do consumidor na cidade do Rio de Janeiro. In: ENCONTRO DA ANPAD, 31., 2007, Rio de Janeiro. Anais... Rio de Janeiro: ANPAD, 2007.

FREIRE, F.; REBOUÇAS, T. R. Uma descrição sucinta do balanço social francês, português, belga e brasileiro. In: SILVA, C. A.; FREIRE, F. (Org.). Balanço social: teoria e prática. São Paulo: Atlas, 2001.

GLOBAL REPORTING INITIATIVE. Diretrizes para relatório de sustentabilidade. 2006. Disponível em: <http://www.globalreporting.org/NR/ rdonlyres/812DB764-D217-4CE8-B4DE15F790EE2BF3/0/G3_GuidelinesPTG.pdf>. INSTITUTO BRASILEIRO DE ANÁLISES SOCIAIS E ECONÔMICAS. Balanço social, dez anos: o desafio da transparência. Rio de Janeiro, 2008. Disponível em: <http://www.balancosocial.org.br/cgi/cgilua.exe/sys/ start.htm?infoid $=164 \&$ sid $=12>$. INSTITUTO ETHOS. Guia para elaboração de balanço social e relatório de sustentabilidade. São Paulo, 2007. Disponível em: <http://www.ethos.org.br/_Uniethos/ Documents/GuiaBalanco2007_PORTUGUES.pdf>. LOYOLA, L. M. T. A empresa e a função social da propriedade. Revista Direitos Fundamentais \& Democracia, Curitiba, v. 1, n. 1, 2007. Disponível em: $<$ http://revistaeletronicardfd.unibrasil.com.br $>$. Acesso em: 4 fev. 2009.

MACHADO FILHO, C. P. Responsabilidade social e governança: o debate e as implicações - responsabilidade social, instituições, governança e reputação. São Paulo: Thomson Learning, 2006.

SCHOMMER, P. C.; ROCHA, F. C. C. As três ondas da gestão socialmente responsável no Brasil: dilemas, oportunidades e limites. In: ENCONTRO DA ANPAD, 31. 2007, Rio de Janeiro. Anais... Rio de Janeiro: ANPAD, 2007.

SHARFMAN, M. P. Changing institutional rules: the evolution of corporate philanthropy 1883-1953. In: Business and Society. University of Oklahoma: Sage Publications Inc., n. 3, v. 33, p. 236-269, dez. 1994. TORRES, C. Responsabilidade social das empresas (RSE) e balanço social no Brasil. In: SILVA, C. A.; FREIRE, F. (Org.). Balanço social: teoria e prática. São Paulo: Atlas, 2001.

UNITED NATIONS. Guidance on corporate responsibility indicators in annual reports. United Nations: New York and Geneva, 2008.

UNITED NATIONS. 2008 Review of the reporting status of corporate responsibility indicators. Reported by the UNCTAD secretariat. TD/B/C.II/ISAR/CRP.2. Distr.: Restricted, 2008b. 


\section{Annex I - List of Brazilian enterprises in the study}

1. Açucar Guarani

2. American Banknote

3. $\mathrm{B} 2 \mathrm{~W}$

4. Banco do Brasil

5. Banco Nossa Caixa

6. BR Malls

7. Brasil Ecodiesel

8. Brasilagro

9. Cia Providência

10. Cosan

11. CPFL Energia

12. CSU Cardsystem

13. Drogasil
14. EDP-Energia do Brasil

15. Embraer

16. Equatorial Energia

17. General Shopping

18. Heringer

19. Iguatemi

20. JBS

21. LIGHT

22. Localiza

23. Lojas Renner

24. Lupatech

25. M.Dias Branco

26. Marfrig
27. Metalfrios

28. Minerva

29. MPX Energia

30. Natura Cosméticos

31. Perdigão

32. Redecard

33. Renar Maçãs

34. Romi

35. São Martinho

36. SLC Agrícula

37. Tractebel Energia

38. WEG

39. Marisa 